\title{
New Design of Solar Photovoltaic and Thermal Hybrid System for Performance Improvement of Solar Photovoltaic
}

\author{
Ridwone Hossain, ${ }^{1,2}$ Al Jumlat Ahmed ${ }^{(D)},{ }^{2,3}$ Sheik Md Kazi Nazrul Islam $\mathbb{D}^{4},{ }^{4}$ Nirupam Saha, ${ }^{5}$ \\ Preetom Debnath, ${ }^{5}$ Abbas Z. Kouzani, ${ }^{6}$ and M. A. Parvez Mahmud ${ }^{6}$ \\ ${ }^{1}$ Department of Electrical and Electronic Engineering, Ahsanullah University of Science and Technology, Dhaka 1208, Bangladesh \\ ${ }^{2}$ Institute for Superconducting and Electronic Materials (ISEM), University of Wollongong, NSW 2500, Australia \\ ${ }^{3}$ Department of Electrical and Electronic Engineering, Khwaja Yunus Ali University, Sirajganj 6751, Bangladesh \\ ${ }^{4}$ School of Mathematical and Physical Sciences, University of Technology Sydney, NSW 2007, Australia \\ ${ }^{5}$ Department of Electrical and Electronic Engineering, United International University, Dhaka 1212, Bangladesh \\ ${ }^{6}$ School of Engineering, Deakin University, Geelong, VIC 3216, Australia
}

Correspondence should be addressed to Al Jumlat Ahmed; jumlat@gmail.com and Sheik Md Kazi Nazrul Islam; smkni979@uowmail.edu.au

Received 12 April 2020; Accepted 9 June 2020; Published 15 July 2020

Academic Editor: Zaiyong Jiang

Copyright (c) 2020 Ridwone Hossain et al. This is an open access article distributed under the Creative Commons Attribution License, which permits unrestricted use, distribution, and reproduction in any medium, provided the original work is properly cited.

\begin{abstract}
Solar photovoltaic (PV) and solar thermal systems are most widely used renewable energy technologies. Theoretical study indicates that the energy conversion efficiency of solar photovoltaic gets reduced about $0.3 \%$ when its temperature increases by $1^{\circ} \mathrm{C}$. In this regard, solar PV and thermal (PVT) hybrid systems could be a solution to draw extra heat from the solar PV panel to improve its performance by reducing its temperature. Here, we have designed a new type of heat exchanger for solar PV and thermal (PVT) hybrid systems and have studied the performance of the system. The PVT system has been investigated in comparison with an identical solar PV panel at outdoor condition at Dhaka, Bangladesh. The experiments show that the average improvement of open circuit voltage $(\mathrm{Voc})$ is $0.97 \mathrm{~V}$ and the highest improvement of $\mathrm{Voc}$ is $1.3 \mathrm{~V}$. In addition, the overall improvement of output power of solar PV panel is $2.5 \mathrm{~W}$.
\end{abstract}

\section{Introduction}

Solar photovoltaic (PV) and solar thermal systems are among the most widely used renewable energy technologies. However, the solar PV and thermal (PVT) hybrid system is not popular to that extent. Solar PV systems are available in different sizes from single solar panel system to large-scale solar PV power plants. And solar thermal systems are mostly used for household and commercial purposes. The operation of solar photovoltaic is highly dependent on weather conditions like temperature, precipitation, air condition, and most importantly solar irradiance. Like all other semiconductor devices, solar PV cells are sensitive to temperature. With the increase in temperature, the band gap energy of semiconductor material gets reduced, so the current increases slightly but the voltage decreases significantly. Therefore, the energy conversion efficiency of silicon solar cell reduces about $0.3 \%$ when its temperature increases by $1^{\circ} \mathrm{C}[1,2]$. The working temperature of solar cell could be as much as $50^{\circ} \mathrm{C}$ above the ambient temperature and consequences of high working temperature are, drop in cell efficiency and permanent structural damage of the solar panel if the thermal stress remains for a longer period [3].

$$
I_{\text {cell }}=I_{0}-I_{\mathrm{ph}}\left(e^{q V / K T}-1\right)
$$

Equation (1) shows how temperature is related to current and voltage of a solar cell, where $I_{0}$ is the dark current, $I_{\mathrm{ph}}$ is the photo current, $q$ is the charge of electron, $V$ is the 


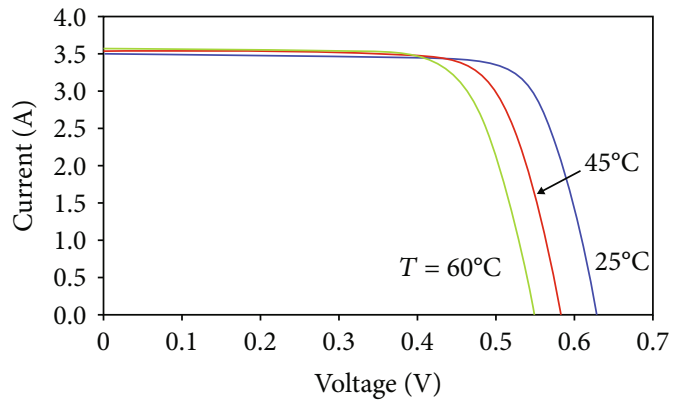

FIGURE 1: The impact of temperature on current and voltage of a solar cell. The reduction in voltage is higher than the increase in current; therefore, the output power of solar cell decreases with increase in temperature.

voltage, $K$ is Boltzmann's constant, and $T$ is the temperature. The simulation result (Figure 1) based on the current Equation (1) of silicon solar cell shows that the voltage of the cell reduces noticeably when its temperature increases. However, the increment of cell current due to temperature raise is negligible. Therefore, the output power of solar cell decreases with the increase in temperature.

When thermal energy system is integrated with the solar photovoltaic system, it is called the photovoltaic and thermal (PVT) hybrid system [4]. Since, the hybrid system utilizes same area for the production of electricity and heat energy, it increases the overall efficiency of the system in terms of energy generation from per unit area [5]. The solar PVT system can be used for crop drying and air heating, and it can also be integrated with building facade, known as the building integrated PVT system (BI/PVT) [6]. The theoretical calculation says that the overall energy conversion efficiency of a hybrid system could be $60-80 \%$ [7]. However, the first priority of most of the hybrid systems is to bring down the temperature of solar PV, so that its electrical performance can be improved [8]. Different types of heat exchanger have been integrated with solar PV panel for improving its efficiency by reducing its temperature, for example, the use of fins, hexagonal honeycomb heat exchanger, and $\mathrm{V}$-grooved absorber [9]. Three different designs like V-groove, honeycomb, and stainless steel wool have been installed horizontally into the channel located at the back side of a solar PV panel to improve performance of the PV panel [10]. In another case, 12 units of rectangular tunnel have been installed parallel at the back side of a solar PV panel as a heat exchanger to improve the efficiency of the system [1, 11]. It has been reported that four different hybrid systems like (i) PV with water flow, (ii) PV with water flow and glazing, (iii) PV with air circulation, and (iv) PV with air circulation and glazing have been experimented based on commercial PV panel at outdoor conditions. The result shows that PV cooling can increase the electrical efficiency of the PV panel. The efficiency can improve further by using a booster diffuse reflector [12]. However, the hybrid system with solar PV panel underneath of a glazing system has its own disadvantages. The electrical efficiency of the panel reduces due to the absorption and reflection of sunlight by the glazing system [13]. Recent study shows that the water-based PVT system can improve the power of the solar PV panel by $6 \%$ in average compared to the conventional PV panel [14]. Another study shows that the top surface of the solar PV panel cooling by water can improve the panel efficiency by almost $1.5 \%$ [15]. However, the water-based PVT system requires more energy to circulate the working fluid and the system is more complex. Different PVT systems have been tested under same environmental conditions using artificial neural network- (ANN-) based multilayer perceptron (MLP) system [16]. The study shows that the nanofluid/nanophase change material- (PCM-) based system enhances both the electrical and thermal efficiency. It also improves the voltage significantly. Among various PVT systems such as air, water, air/water, phase change material (PCM), and nanofluid, it is found that the air heater PVT system is promising for future preheating air applications [17]. The PVT system has the potential to integrate thermoelectric generator with the system to produce electricity from the thermal energy that is extracted from the solar panel $[18,19]$.

Here, we have proposed a hybrid system with a new type of heat exchanger for improving performance of the solar PV panel. As shown in Figure 2, the heat exchangers are arranged in such a way that they guide air to circulate in waveform through the channels located inside the solar thermal system. The upper side of heat exchangers is bended and is attached to the back side of the solar PV panel so that conduction heat transfer can happen from the PV panel to the heat exchanger. Performance of the PVT system has been investigated with respect to a solar PV panel with identical specification. Both the systems, solar PV and thermal (PVT system) and normal solar PV panel (normal system), have been examined simultaneously at outdoor conditions.

\section{Materials and Method}

The solar PV panel attached to the heat exchanger and internal construction of the heat exchanger are shown in Figures 3(a) and 3(b), respectively. The encloser of the heat exchanger is made of corrosion resistive stainless-steel sheet, and exposed surfaces to air of the heat exchanger are insulated using the glass wool. The fins guide air circulation; the channels are made of aluminium. The upper side of fins is bended and tightly attached to the back surface of the solar PV panel, so that heat transfer from the PV panel to fins occurs by the conduction process. Equation (2) is the heat flow rate across materials by conduction.

$$
\frac{Q}{t}=\frac{k A d T}{d}
$$

where $k$ is the thermal conductivity of the material, $A$ is the heat transfer area, $d T$ is the temperature difference across the materials, and $d$ is the thickness. So, the conduction process of heat increases with the increase in thermal conductivity of the material and increase in the heat transfer area. But the heat transfer decreases with the thickness of the transferring material. Thermal conductivity of aluminium is less than that of copper, but aluminium is cost effective, so it has been used as heat transferring material. Since heat transfer rate is 


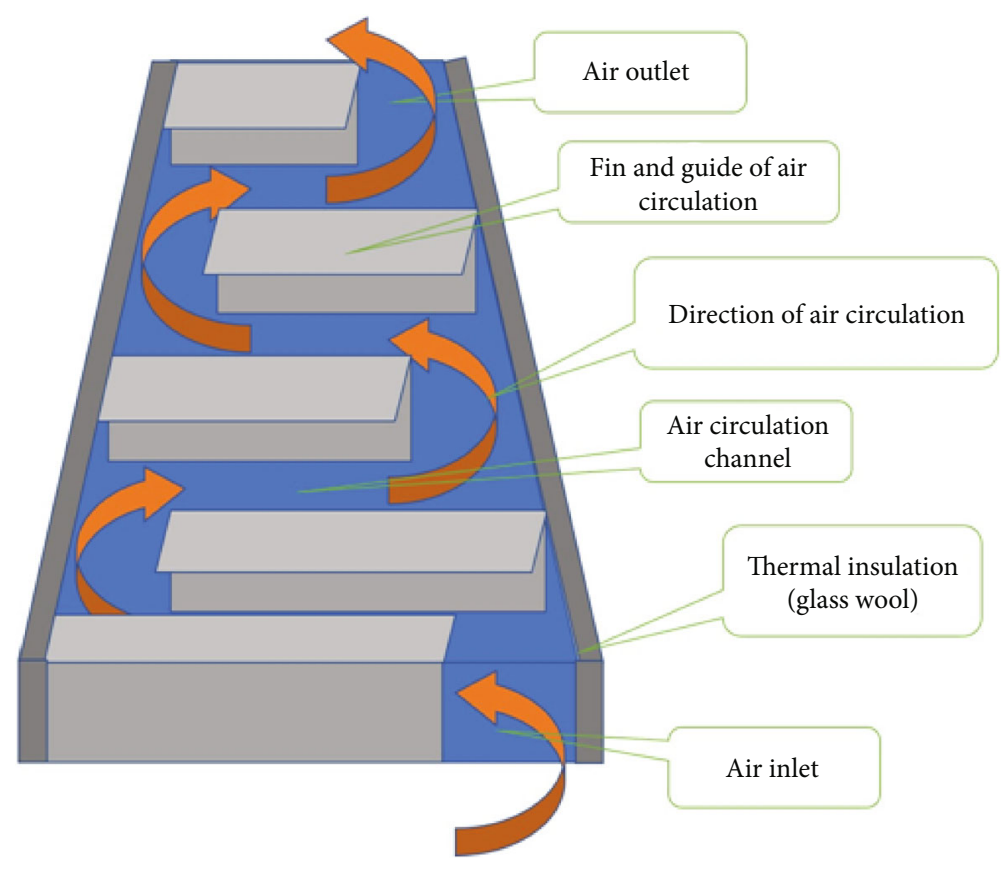

FIgURE 2: Schematic of solar thermal system. The solar PV panel is to set on the top of the solar thermal system.

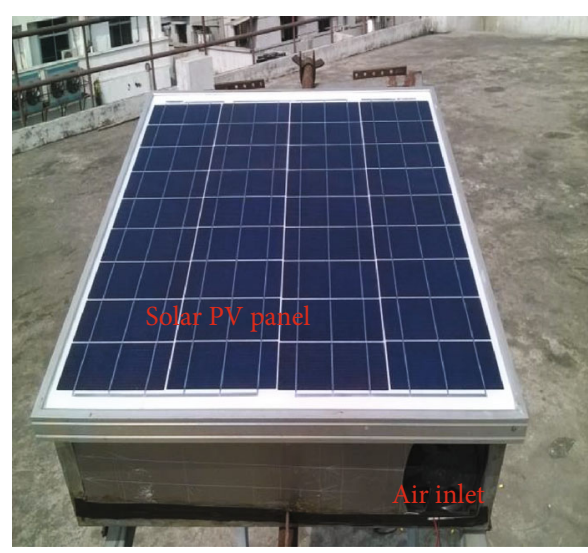

(a)

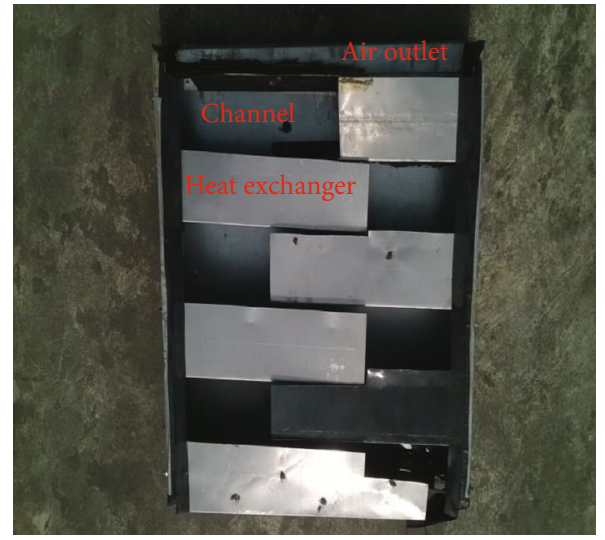

(b)

Figure 3: (a) The solar PV panel installed on the top of the heat exchanger. (b) Internal construction of the heat exchanger.

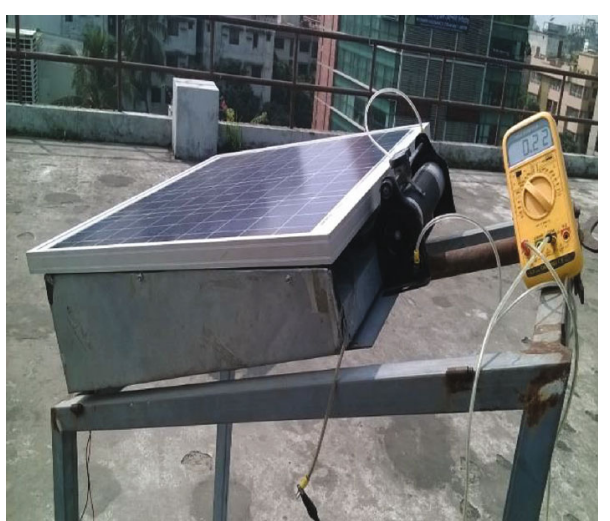

(a)

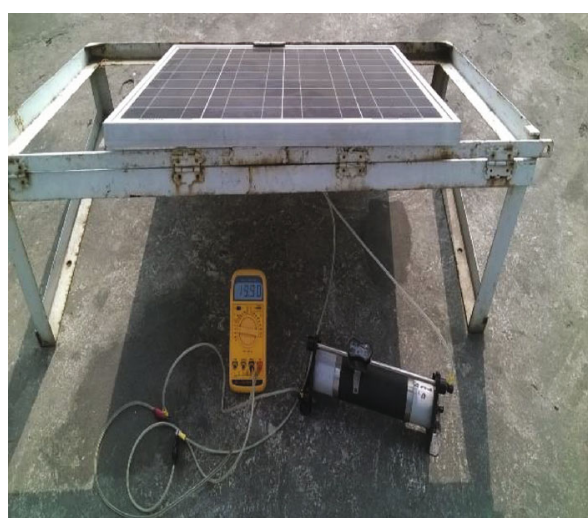

(b)

FIGURE 4: Digital multimeter is connected to measure the voltage and current. (a) The PVT system and (b) the normal system. 
inversely related to thickness of heat exchange material, therefore, thin aluminium sheet ( $1 \mathrm{~mm}$ of thickness) has been used as heat exchange material. The heat transferring area of the sheet has been kept as long as possible to increase the heat transfer.

Performance of the PVT system has been evaluated with respect to an identical solar PV panel at outdoor environmental condition. Identical multicrystalline solar PV panels of $50 \mathrm{~W}$ and $12 \mathrm{~V}$ rating have been used in both PVT and normal systems [20]. Both the systems have been measured simultaneously at outdoor condition for several days. The experiments are carried out at Dhaka, Bangladesh. Digital multimeters have been used to measure the voltage and current of solar PV panels. The temperature of air at inlet and outlet of the PVT system has been measured by thermocouple. The experimental setup for performance evaluation is shown in Figure 4.

\section{Results and Discussion}

Different parameters, for example, air temperature at inlet and outlet of the PVT system, voltage and current of the PVT system and the normal system have been measured to evaluate performance of the systems. The power output of the solar PV panels is calculated based the on the voltage and current readings. Temperature of air at intel and outlet of the PVT system, open circuit voltage, and short circuit current readings of the systems have been taken in every 10 min interval.

3.1. Temperature of Air at Intel and Outlet of PVT System. Except two readings, temperature of air at outlet of the PVT system is always higher than temperature of air at inlet of the system as shown in Figure 5. It indicates that the heat is effectively transferred from the PVT system to the air when the air is circulating through the channels of the heat exchanger. Average temperature difference of air between outlet and inlet is $2.6^{\circ} \mathrm{C}$, and maximum difference is more than $4^{\circ} \mathrm{C}$. The result shows that the heat exchanger works properly to transfer heat from the PVT system to the circulation air and it should help to improve the electrical output of the PVT system. The air flow rate is an important parameter to performance evaluation of the solar PV and thermal hybrid system. The air flow rate through the heat exchanger can be regulated by controlling the speed of the cooling fan. In our experiments, we have used natural air flow and have not measured the air flow rate.

3.2. Open Circuit Voltage and Short Circuit Current. The open circuit voltage (Voc) measurement of the PVT and the normal systems are shown in Figure 6. There is a significant improvement in Voc of the PVT system compared to the normal system. The Voc of the PVT system is always higher than the Voc of the normal system throughout the day. This result indicates that the heat exchanger is successfully transferring heat from the PVT system to the circulating air. The average improvement in Voc is $0.97 \mathrm{~V}$, and the maximum improvement in $\mathrm{Voc}$ is $1.3 \mathrm{~V}$. On the other hand, the reduction in short circuit current (Isc) of the PVT system

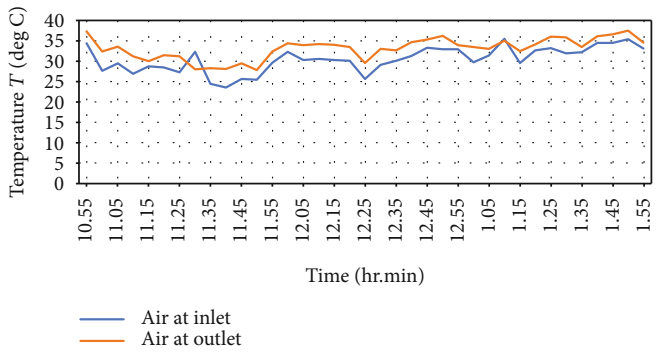

Figure 5: Temperature of air at inlet and outlet of the PVT system. Average difference in temperature of inlet air and outlet air is $2.6^{\circ} \mathrm{C}$, and maximum difference in temperature is more than $4^{\circ} \mathrm{C}$.

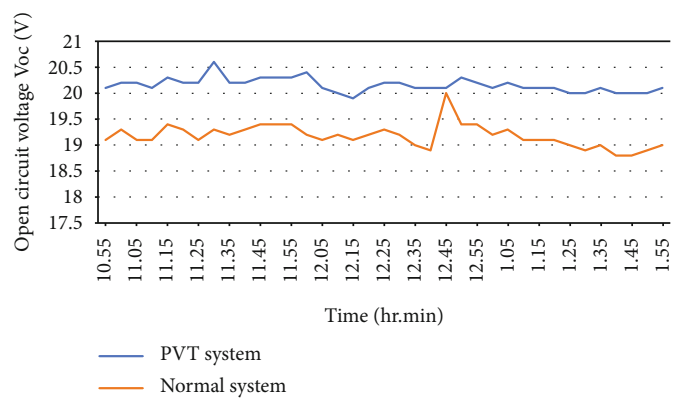

FIGURe 6: Open circuit voltage (Voc) of the PVT and the normal system. The average improvement in $\mathrm{Voc}$ is $0.97 \mathrm{~V}$ where the maximum improvement in $\mathrm{Voc}$ is $1.3 \mathrm{~V}$ for the PVT system compared to the normal system.

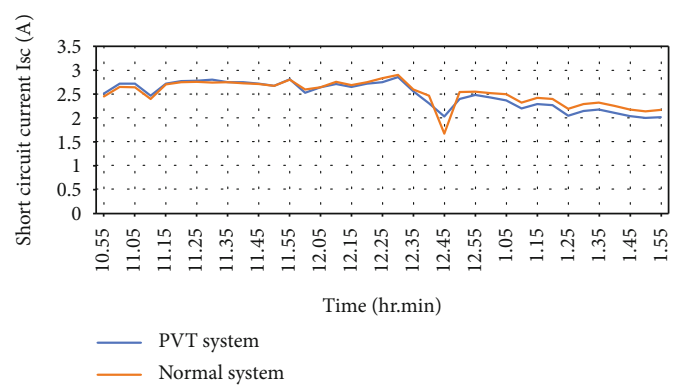

FIgURe 7: Short circuit current (Isc) of the PVT and the normal system. Average reduction in Isc of PVT system is $0.04 \mathrm{~A}$ compared to the normal system and maximum reduction in Isc is $0.16 \mathrm{~A}$.

compared to the normal PV system in not significant as shown in Figure 7. The average reduction in Isc of the PVT system is $0.04 \mathrm{~A}$ compared to the normal system and maximum reduction in Isc is $0.16 \mathrm{~A}$. The air temperature readings at inlet and outlet of the PVT system and voltage and current readings of the PVT and normal systems support each other.

3.3. Output Power of PVT System. The output power of both systems has been calculated from the Voc and Isc readings. Figure 8 shows that there is an overall improvement in output power of the PVT system in comparison to the normal system. The average improvement in output power of the PVT system is $2.5 \mathrm{~W}$, and maximum improvement is $7.4 \mathrm{~W}$. Temperature difference between the inlet air and outlet air of the PVT system is a clear indication of temperature drop 


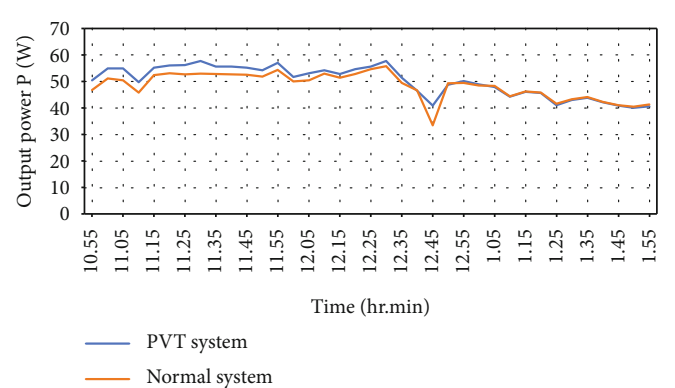

FIGURE 8: Output power of PVT and normal system. Average improvement in output power of PVT system is $2.5 \mathrm{~W}$, and maximum improvement is $7.4 \mathrm{~W}$.

of the PVT system. And improvement in output power of the system is due to this temperature drop. However, the output power of PVT and normal system are almost same, and the PVT system is fairly less effective very effective after $12.55 \mathrm{pm}$. This could be due to the less difference between outlet temperature of the PVT system and the ambient temperature in the afternoon afternoon. The performance of the PVT system is better when the ambient temperature is low compared to the air temperature at the outlet of the system.

\section{Conclusions}

Design of a new heat exchanger for solar PV and thermal hybrid system has been implemented successfully. The performance evaluation of the PVT system in comparison to the normal solar PV panel shows that the new design of heat exchanger successfully transfers heat to the circulating air. And therefore, there is a significant improvement in the open circuit voltage and the output power of solar PV panel. The overall improvement of voltage is $0.97 \mathrm{~V}$, and overall improvement of the output power is $2.5 \mathrm{~W}$.

\section{Data Availability}

The dataset is provided as supplementary material. The dataset file is titled "Data Temp Voc Isc Power".

\section{Conflicts of Interest}

The authors declare that there is no conflict of interest regarding the publication of this paper.

\section{Authors' Contributions}

Al Jumlat Ahmed conceive the idea and experiment design. Nirupam Saha and Preetom Debnath performed the experiments and result compilation. Ridwone Hossain and Sheik Md Kazi Nazrul Islam wrote the manuscript. M. A. Parvez Mahmud and Abbas Z. Kouzani made the scientific explanation and revision of the manuscript.

\section{Acknowledgments}

Authors are grateful to Department of Electrical and Electronic Engineering and Centre for Energy Research of the United International University, Bangladesh, for their technical support. We are thankful to Mohammad Safiqul Islam and Mohammad Mahinuzzaman for their assistance to conduct the experiments. The research is funded by the Undergraduate Project Fund of the United International University.

\section{Supplementary Materials}

The dataset and a video clip on the solar PV and Thermal (PVT) system are provided as supplementary materials. (Supplementary Materials)

\section{References}

[1] G. L. Jin, A. Ibrahim, Y. K. Chean et al., "Evaluation of singlepass photovoltaic-thermal air collector with rectangle tunnel absorber," American Journal of Applied Sciences, vol. 7, no. 2, pp. 277-282, 2010.

[2] M. Noro, R. Lazzarin, and G. Bagarella, "Advancements in hybrid photovoltaic-thermal systems: performance evaluations and applications," Energy Procedia, vol. 101, pp. 496503, 2016.

[3] T. T. Chow, "A review on photovoltaic/thermal hybrid solar technology," Applied Energy, vol. 87, no. 2, pp. 365-379, 2010.

[4] A. S. Joshi, A. Tiwari, G. N. Tiwari, I. Dincer, and B. V. Reddy, "Performance evaluation of a hybrid photovoltaic thermal (PV/T) (glass-to- glass) system," International Journal of Thermal Sciences, vol. 48, no. 1, pp. 154-164, 2009.

[5] M. Noro and R. M. Lazzarin, "Hybrid PhotoVoltaic-thermal heat pump systems: energy and economic performance evaluations in different climates," International Journal of Low-Carbon Technologies, vol. 13, no. 1, pp. 7683, 2018.

[6] A. Riaz, R. Liang, C. Zhou, and J. Zhang, "A review on the application of photovoltaic thermal systems for building façades," Building Services Engineering Research and Technology, vol. 41, no. 1, pp. 86-107, 2020.

[7] B. J. Huang, T. H. Lin, W. C. Hung, and F. S. Sun, "Performance evaluation of solar photovoltaic/thermal systems," Solar Energy, vol. 70, no. 5, pp. 443-448, 2001.

[8] A. Ramos, M. A. Chatzopoulou, I. Guarracino, J. Freeman, and C. N. Markides, "Hybrid photovoltaic-thermal solar systems for combined heating, cooling and power provision in the urban environment," Energy Conversion and Management, vol. 150, pp. 838-850, 2017.

[9] S. Diwania, S. Agrawal, A. S. Siddiqui, and S. Singh, "Photovoltaic-thermal (PV/T) technology: a comprehensive review on applications and its advancement," International Journal of Energy and Environmental Engineering, vol. 11, no. 1, pp. 33-54, 2020.

[10] M. Y. H. Othman, F. Hussain, K. Sopian, B. Yatim, and H. Ruslan, "Performance study of air-based photovoltaicthermal (PV/T) collector with different designs of heat exchanger," Sains Malaysiana, vol. 42, no. 9, pp. 1319-1325, 2013.

[11] G. Jin, H. Ruslan, S. Mat, M. Y. Othman, A. Zaharim, and K. Sopian, "Experiment study on single-pass photovoltaicthermal (PV/T) air collector with absorber," in 9th WSEAS International Conference on System Science and Simulation 
in Engineering, ICOSSSE'10, pp. 435-438, Iwate Prefectural University, Japan, October 2010.

[12] Y. Tripanagnostopoulos, T. Nousia, M. Souliotis, and P. Yianoulis, "Hybrid photovoltaic/thermal solar systems," Solar Energy, vol. 72, no. 3, pp. 217-234, 2002.

[13] E. Erdil, M. Ilkan, and F. Egelioglu, "An experimental study on energy generation with a photovoltaic (PV)-solar thermal hybrid system," Energy, vol. 33, no. 8, pp. 1241-1245, 2008.

[14] H. A. Kazem, "Evaluation and analysis of water-based photovoltaic/thermal (PV/T) system," Case Studies in Thermal Engineering, vol. 13, article 100401, 2019.

[15] M. A. Arefin, "Analysis of an integrated photovoltaic thermal system by top surface natural circulation of water," Frontiers in Energy Research, vol. 7, no. 97, 2019.

[16] A. H. A. Al-Waeli, K. Sopian, J. H. Yousif, H. A. Kazem, J. Boland, and M. T. Chaichan, "Artificial neural network modeling and analysis of photovoltaic/thermal system based on the experimental study," Energy Conversion and Management, vol. 186, pp. 368-379, 2019.

[17] A. H. A. Al-Waeli, K. Sopian, H. A. Kazem, and M. T. Chaichan, "Photovoltaic/thermal (PV/T) systems: status and future prospects," Renewable and Sustainable Energy Reviews, vol. 77, pp. 109-130, 2017.

[18] A. J. Ahmed, M. S. A. Hossain, S. M. Kazi Nazrul Islam et al., "Significant improvement in electrical conductivity and Figure of Merit of nanoarchitectured porous $\mathrm{SrTiO}_{3}$ by La doping optimization," ACS Applied Materials \& Interfaces, 2020.

[19] A. J. Ahmed, S. M. K. Nazrul Islam, R. Hossain et al., "Enhancement of thermoelectric properties of La-doped $\mathrm{SrTiO}_{3}$ bulk by introducing nanoscale porosity," Royal Society Open Science, vol. 6, no. 10, article 190870, 2019.

[20] Solarland, SLP050-12 High Efficiency Multicrystalline PV Module, Solarland, 2010. 